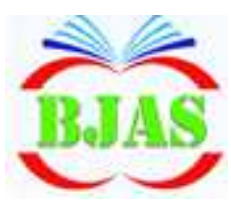

ISSN $1814-5868$
Available online at http://journal.bajas.edu.iq

College of Agriculture, University of Basrah

DOi:10.21276/basjas

Basrah J. Agric. Sci., 31(2): 76-81, 2018

\section{Basrah Journal of Agricultural Sciences}

E-ISSN: 2520-0860

\title{
Occurrence of whirling disease symptoms in cultured common carp in Basrah, Iraq
}

\author{
Ebtihal K.J. Al-Nowfal ${ }^{1}$, Najim R. Khamees ${ }^{1 *}$ \& Sawsan S. Al-Haroon ${ }^{2}$ \\ ${ }^{1}$ Department of Fisheries and Marine Resources, College of Agriculture, University \\ of Basrah, Iraq. \\ ${ }^{2}$ Department of Pathology, College of Medicine, University of Basrah, Iraq \\ *Corresponding author e-mail: khamees54@yahoo.com \\ Received 8 April 2018; Accepted 30 April 2018; Available online 6 March 2019
}

\begin{abstract}
A total of 128 fish samples including 70 Cyprinus carpio Linnaeus, 1758, 10 Leuciscus vorax (Heckel, 1843), 40 Oreochromis aureus (Steindachner, 1864) and eight Planiliza abu (Heckel, 1843) were collected during the period from November 2016 to May 2017. Seven different localities (floating cages, earthen ponds and natural water) in Basrah were investigated. Among some detected fish diseases, whirling disease symptoms was reported for the first time in Iraq in April 2017, from two $C$. carpio cultured in earthen fish ponds of Marine Science Centre, University of Basrah. The infested fish were dwarfed, with abnormal big head and small body. Grossly signs of the diseases represent fins and tail deformities in addition to open ulcers and losing of scales, and necrosis of skin and muscles. Internally, fish suffered of muscles ecchymosis and vertebral deformities. Histological sections revealed that the spinal cord had healthy structure.
\end{abstract}

Keywords: Fish diseases, Whirling disease symptoms, Myxobolus sp., Cyprinus carpio, Histopathology.

\section{Introduction}

Recently, inland fish culture in Iraq is developing rapidly. Many such projects are scattered in Basrah province, as earthen fish ponds and floating cages with improper fish health management. Thus, infectious fish diseases are spreading among cultured and wild fishes in Basrah (Al-Shemmari, 2017). This problem could be enhanced because of uncontrolled import and transport of alive aquarium and commercial fishes (Khamees et al., 2013). Moreover the Tigris-Euphrates basin (including Shatt Al-Arab River and the adjacent water bodies) suffer from depleted freshwater supplies, and high levels of different pollutants (Freyhof et al., 2014), so fish will be under stress of poor water quality and turned to be easily infested by opportunistic pathogens (Noga, 2010). Diseases of cultured fishes in Basrah had little attention, however Khamees \& Ali 
(2013) and latterly Taher (2014) reported the occurrence of the viral disease, spring viraemia of carp (SVC) from wild prussian carp and cultured common carp, respectively. Al-Shemmari (2017) isolated 13 bacterial species from cultured common carp, some wild fish and from their aquatic environments. Al-Taee et al. (2017) carried out an investigation on the occurrence of species of potentially pathogenic species of Vibrio. They isolated $V$. alginolyticus as predominant species and other five highly pathogenic forms, from Cyprinus carpio, Coptodon zillii and Planiliza subviridis. In this study, symptoms of whirling disease is reported for the first time in Iraq from cultured carp. The fish site (2017) define it as acute disease caused by the cnidarian Myxobolus cerebralis which infest fish juveniles via the bottom dweller worms of the genus Tubifex. This disease may cause high commercial losses, because it can transfer rapidly via water, birds, infested fish or even by human activities (Noga, 2010). According to Bondad-Reantaso et al. (2001), the successful methods of control and treatment of fish disease can be achieved through accurate diagnosis, from which the examination of histological sections of the infected tissues is crucial step.

\section{Materials and Methods}

A total of 128 fish were collected during the period from November 2016 till May 2017, including 70 Cyprinus carpio Linnaeus, 1758, 10 Leuciscus vorax (Heckel, 1843), 40 Oreochromis aureus (Steindachner, 1864) and eight Planiliza abu (Heckel, 1843). Fish were sampled using cast nets or draft nets from seven different stations in Basrah as follows: Floating cages at Al-Hartha region $\left(30^{\circ} 37^{\prime} 24.8^{\prime \prime} \mathrm{N}\right.$ and $\left.47^{\circ} 45^{\prime} 29.4^{\prime \prime} \mathrm{E}\right)$, floating cages of Ahwar company (30 $38^{\prime} 24.6^{\prime \prime} \mathrm{N}$ and $\left.47^{\circ} 41^{\prime} 32.9^{\prime \prime} \mathrm{E}\right)$, earthen ponds of the Marine Science Centre at Garmat Ali $\left(30^{\circ} 33^{\prime} 39.91^{\prime \prime}\right.$ $\mathrm{N}$ and $47^{\circ} 44^{\prime} 28.34^{\prime \prime} \mathrm{E}$ ), earthen ponds of AlSabah culture $\left(30^{\circ} 20^{\prime} 10.36^{\prime \prime} \mathrm{N}\right.$ and $\left.48^{\circ} 14^{\prime} 46.25^{\prime \prime} \mathrm{E}\right)$, earthen ponds at Kteban region $\left(30^{\circ} 42^{\prime} 48^{\prime \prime} \mathrm{N}\right.$ and $\left.47^{\circ} 46^{\prime} 52^{\prime \prime} \mathrm{E}\right)$, Shatt Al-Arab River at Basrah city center $\left(30^{\circ} 29^{\prime} 51^{\prime \prime} \mathrm{N}\right.$ and" 4751'39" E) and Shatt
Al-Arab River at Al-Dair town $\left(30^{\circ} 47^{\prime} 51^{\prime \prime} \mathrm{N}\right.$, $47^{\circ} 34^{\prime} 59^{\prime \prime}$ E). Fish specimens were kept in cool box and transferred to the laboratories of the Department of Fisheries and Marine Resources, where it was examined externally and internally for any disease signs. Fish weight and total length were measured, and the histological work was achieved. BondadReantaso et al. (2001) and Noga (2010) were followed to dissect fish, obtaining tissue samples and diagnose the disease, respectively. Rotary microtome was used to prepare 5-7 micrometer tissue sections. Permanent slides of histological sections were prepared according to Humason (1972). This method was slightly modified mainly in the fixation step by using $10 \%$ formalin instead of Bouin's fluid to fix the tissues for four hours and in the step of dehydration of the samples, that was carried out using only three alcohol solutions $(70 \%, 85 \%$ and $95 \%$ ethanol). Photomicrography was achieved using phase contrast Olympus microscope. Durand (2016) and Froese \& Pauly (2017) were followed to check validity of fish scientific names.

\section{Results}

Two females out of 70 C. carpio (14-40 cm in total length and 26-778 gm. in weight) were found infected with whirling disease symptoms. Other three fish species were unaffected. The diseased fish were collected in $5^{\text {th }}$ April, 2017 from the ponds of Marine Science Centre. Fig. (1) shows uninfected specimen, while Fig. (2) represents one year C. carpio suffer from acute whirling disease symptoms. The external signs of the disease represented by poor growth (dwarfed fish), tail and fins deformities, losing of scales in addition to exist of open red ulcers in the site of the twisted and very short caudal peduncle (Fig. 2).

The internal signs of whirling disease are showed in Figs. (3 \& 4). Internally the infected fish suffered from red sores and white areas (i.e. the sporocysts of the causative agent) in the muscles around the affected tissues (Fig. 3). Fig. (4) indicates vertebral column of uninfected fish (upper), and another one of infected C. carpio. 


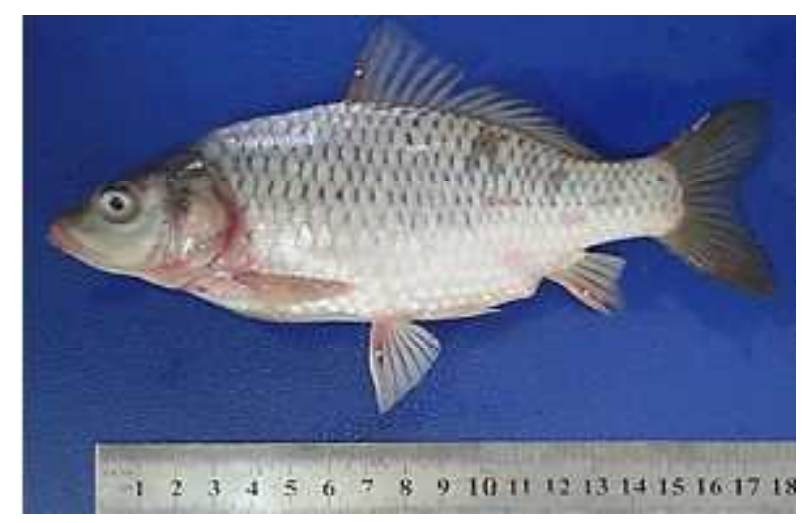

Fig. (1): Healthy $C$. carpio without any external signs of whirling disease.

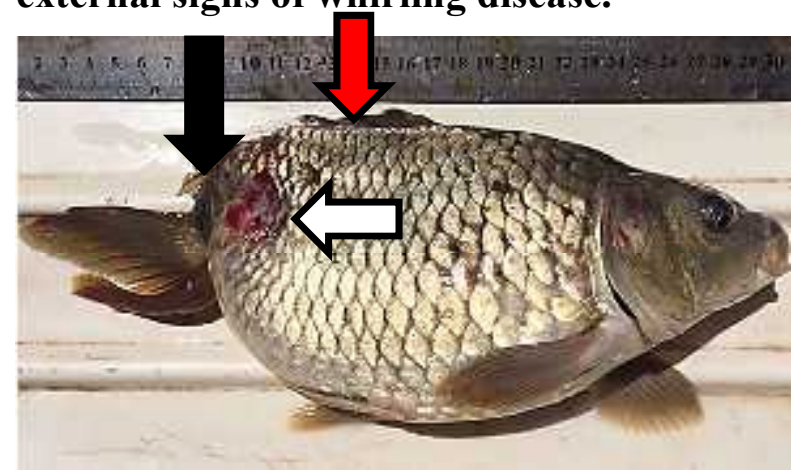

Fig. (2): An infected $C$. carpio with whirling disease, (Black arrow indicates deformities of caudal fin and peduncle; Red arrow indicates deformities of dorsal fin; White arrow indicates open skin ulcer and losing of some scales).

The infected vertebral column appear with many signs of deformities as the atrophy of vertebra 16 and 17, and shifting or narrowing the lateral spinal pores of many vertebra in addition to severe deformities of vertebra and neural and heamal spines .

Cross sections were prepared from the infected part of the vertebral column. The sections revealed that the spinal cord has its normal structure (Plate 1, white arrow), which consists of adipose tissue (plate 1, T) and inner tissue of the spinal cord (plate 1, S). Both tissues were found without any significant pathogenicity.

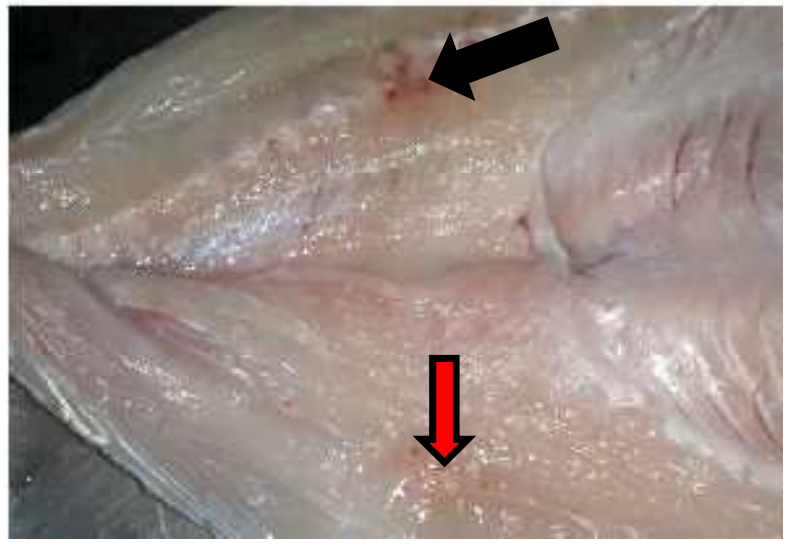

Fig. (3): Internal signs of whirling disease in an infected $C$. carpio. black arrow indicate red sores and red arrow indicates white sac of sporocysts.

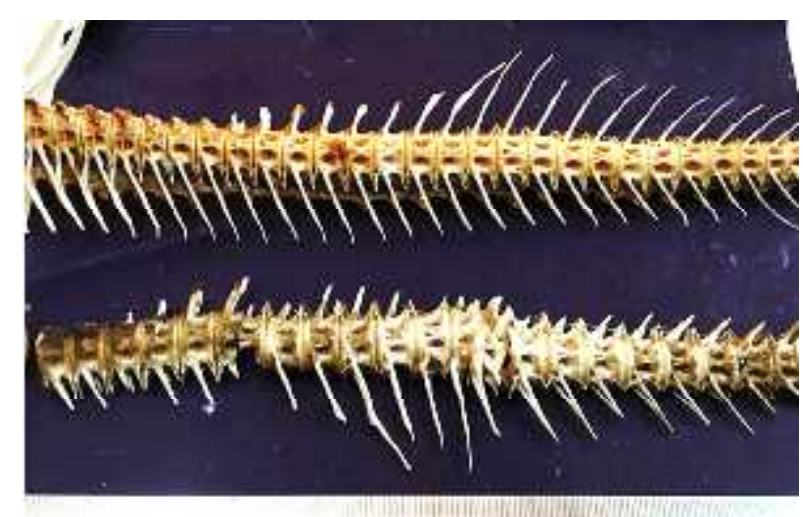

8 I) IH I 12 13 $1+151617181920212223$ ?

Fig. (4): Vertebral column of uninfected $C$. carpio (upper) and of infected fish (lower).

\section{Discussion}

Whirling disease was recorded firstly since more than a century from Rainbow trout in Germany. Later it was recorded from most European countries, South Africa and North America, where its causative agent was identified as Myxobolus cerebralis. This myxozoan enters the host after piercing the tissues by its polar filaments. M. cerebralis needs a tubificid oligochaete to complete life cycle (Wikipedia, 2017). 


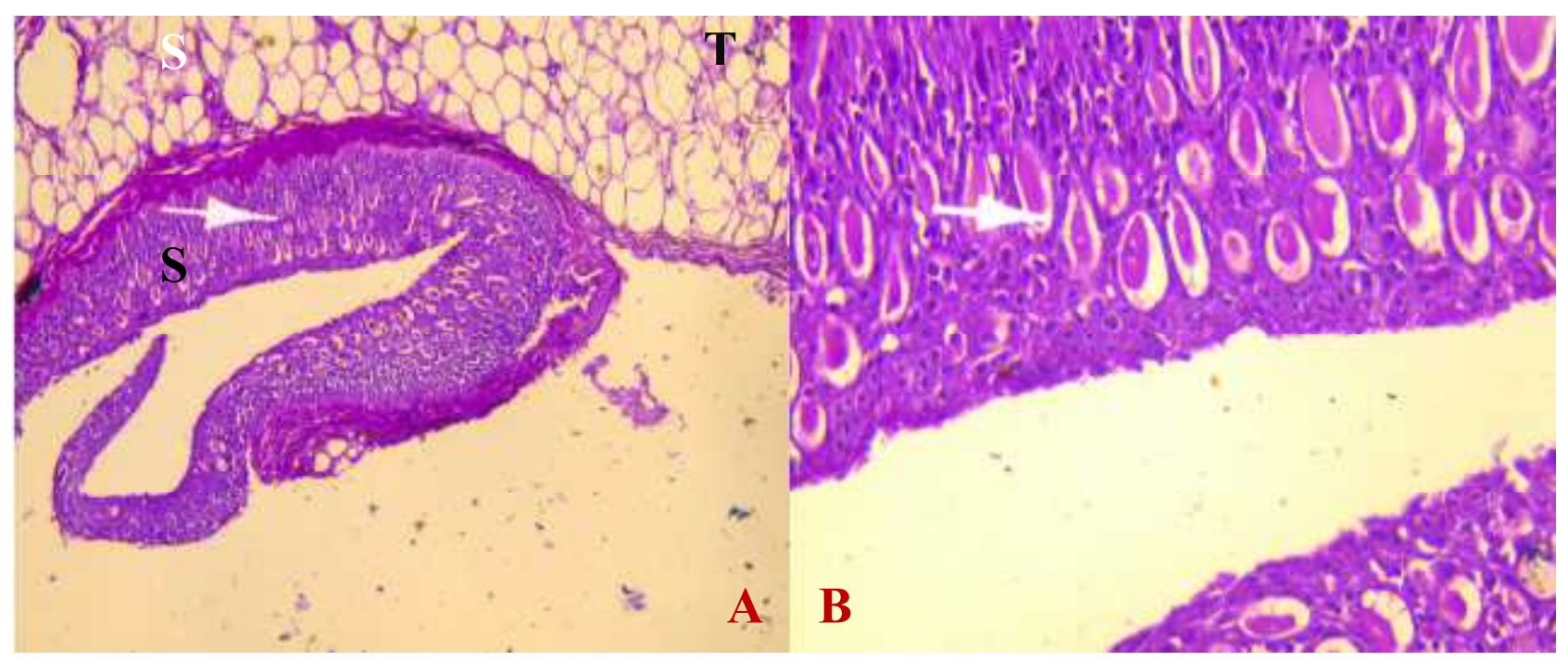

Plate (1): Cross section of vertebral column of infected $C$. carpio (H \& E stain). White arrow indicate tissue of the spinal cord. Adipose tissues (T) and inner tissues of spinal cord (S). Magnifications, 100X in $A$ and 400X in $B$.

It infect cultured juvenile fishes and causes skeletal deformation and neurologic damages, for that, infected fish swims around its horizontal axes, and can't feed perfectly and being dwarfed (Noga, 2010). Severe damages were noticed in the vertebra and the nearby muscles of the infected fish of the present study. According to Faisal (2017), sporocysts of $M$. cerebralis damage fish tissues during its migration from site of infection to another, using polar filaments and caudal spines to pierce cells.

The electronic site AIS (2017), stated that whirling disease was firstly recorded in Europe in 1903 from cultured trout, and transported to USA via the infected fish during 1950. This site reported that the causative agent can tolerate low water temperature and move from area to another via the water or sediment movement in addition to its ability to transmitted with fishes or birds or even by human activities. The occurrence of the disease in the present study, indicates the probability of its transport by one or more of the mentioned paths.
The disease was found to affect cartilages and bones and only rarely affect tissues of the neural system. However the hind part of the brain might be affected as a result of the pressure coming from the inflamed nearby tissues, and for that fish will swim irregularly. Dark spots might be appear on the skin of infected fish plus twisted body, so it will turn to be priceless and consumers will ignore such spoiled stuff (Noga, 2010).

\section{MacConnell \& Bartholomew} published comprehensive revision on whirling disease. They wrote on its geographical distribution which is still expanded to Asia, North America, Africa and Oceania. That study revealed that the infective stage of $M$. cerebralis (viz. Triactinomyxon) leave its intermediate hosts (T. tubifex) and bore in fish body using its sharp appendages, then thousands of spores will released. Morphological fish abnormalities appear then, and it became more advanced with time, while more spores released.

Jawad et al. (2015) recorded vertebral deformities in the cyprinid fish Luciobarbus 
xanthopterus. The fish was collected from AlHowaza Marsh in Mesan province, Iraq during March 2009. Morphologically, the fish showed whirling disease symptoms, but the authors exhibited a heredity disease. They didn't mention any efforts to detect any causative agent. We think it was species of Myxobolus since the temperature of the water was low, and March is the season of reproduction of the host, when Myxobolus release its infective stages (MacConnell \& Bartholomew, 2012).

According to Mhaisen et al. (2016) seven species of the genus Myxobolus were already recorded from Basrah fishes, no once reported from spinal cord of fishes. Sporocysts were very obvious in the present study, and indicates the presence of Myxobolus sp.

While $M$. cerebralis known from Salmonids from different parts of the world (Lom \& Dykova, 2006), Longshaw et al. (2003) described Myxobolus buckei as a new pathogenic parasite from the spinal column of three cyprinid fishes from England. Longshaw (2004) listed 20 Myxobolus species reported from cartilage or implicated in spinal deformities and compared with $M$. buckei Longshaw, Frear \& Feist, 2003.

\section{Conclusions}

The record of parasitic whirling disease in cultured fish, indicates the presence of the cnidarian parasites of the genus Myxobolus. Such parasites cause heavy losses since the infected fish may suffer from sluggish movement and emaciated due to weak feeding and/or being easy prey. The infected fish loss its marketable due to skeletal deformities.

\section{Acknowledgements}

Thanks are due to Prof. Dr. Furhan T. Mhaisen, Katrineholm, Sweden, who provide us with some references and information on parasites of Myxobolus of Iraq. Special thanks are due to Dr. Atheer H. Ali and Dr. Thamir K. Adday from Department of Fisheries and Marine Resources, College of Agriculture, University of Basrah, Iraq for their support during the laboratory work.

\section{References}

Al-Shemmari, N.A.H. (2017). Isolation and diagnosis of bacteria associated with some disease infections in some fishes in Basrah governorate, Iraq. M. Sc. Thesis, College Agric., Univ. Basrah: 122 pp. (In Arabic).

Al-Taee, A.M.R.; Khamees, N.R. \& AlShammari, N.A.H. (2017). Vibrio species isolated from farmed fish in Basra city in Iraq. J. Aquac. Res. Develop., 8: 472. doi: 10.4172/2155-9546.1000472.

AIS (Aquatic Invasive Species) (2017). Whirling disease. Available at: www.in.gov./dnr/WHIRLING.DISEASE.p df. (Accessed on 18.12.2017).

Bondad-Reantaso, M.G.; McGladdery, S.E.; East, I. \& Subasinghee, R.P. (2001). Asia diagnostic guide to aquatic. animal diseases. FAO fish. tech. paper No. 402/2: 230pp.

Durand, J.-D. (2016). Implications of molecular phylogeny for the taxonomy of Mugilidae. In: Crosetti, D. and blabber, S.J.M. (Eds.). Biology, ecology and culture of grey mullet (Mugilidae). Taylor and Francis group, Boca Raton: 22-41.

Faisal, M. (2017). What is whirling disease? Available at: https://www.ncrac.org/files/biblio/whirling 2.pdf. (Accessed on 18.12.2017).

Freyhof, J.; Ekmekçi, F.G.; Ali, A.; Khamees, N.R.; Özuluğ, M.; Hamidan, N.; Küçük, F. \& Smith, K.G. (2014). Freshwater fishes. Pp: 19-42 In: Smith, K.G.; Barrios, V.; 
Darwall, W.R.T. and Numa, C. (Eds.). The status and distribution of freshwater biodiversity in the eastern Mediterranean. IUCN publ., Cambridge, Malaga and gland: 129pp.

Froese, R. \& Pauly, D. (eds.) (2017). FishBase. World Wide Web electronic publication. www.fishbase.org. (Ver. O2/ 2017)

Humason, G.L. (1972). Animal tissue techniques. $3^{\text {rd }}$ edit., W.H. Freeman publ., San Francisco: 641pp.

Jawad, L.A.; Al-Faisal, A.J. \& Al-Mukhtar, M. (2015). A case of vertebral coalescence in Luciobarbus xanthopterus (Heckel, 1843) (Pisces: Cyprinidae) obtained from the lower reaches of Mesopotamia. Travaux du Muséum National d'Histoire Naturelle “Grigore Antipa” 57: 127-132.

Khamees, N.R. \& Ali, A.H. (2013). Spring viraemia of carp (SVC), a lethal disease in wild and cultured fishes in Basrah province, Iraq. The $5^{\text {th }}$ Int. Conf. Microbiol. Biotechnol., Coll. Sci., Univ. Basrah, 2-3 April 2013. (Abstract)

Khamees, N.R.; Ali, A.H.; Abed, J.M. \& Adday, T.K. (2013). First record of striped catfish Pangasianodon hypophthalmus (Sauvage, 1878) (Pisces: Pangasiidae) from inland waters of Iraq. Basrah $\mathrm{J}$. Agric. Sci., 26 (Spec. Issue 1): 184-197.

Lom, J. \& Dykova, I. (2006). Myxozoan genera: definition and notes on taxonomy, life-cycle terminology and pathogenic species. Fol. Parasitol., 53: 1-36.

Longshaw, M. (2004). Studies on myxozoan parasites of freshwater fish and invertebrate hosts. Ph. D. Thesis. Univ. Plymouth: 350pp.

Longshaw, M.; Frear, P. \& Feist, S.W. (2003), Myxobolus buckei sp. 1t (Myxozoa), a new pathogenic parasite from the spinal column of three cyprinid fishes from the United Kingdom Fol. Parasitol., 50: 251-262

MacConnell, E., \& Bartholomew, J.L. (2012). Whirling disease of Salmonids. available at: afsfhs.org/perch/resources/14069236943.2.5 Whirling Disease 2012 pdf. (accessed on 19.12.2017).

Mhaisen, F.; Ali, A., \& Khamees, N. (2016). Checklists of protozoans and myxozoans of freshwater and marine fishes of Basrah Province, Iraq. Mesopot. J. Mar. Sci., 1: 29-52.

Noga, E.J. (2010). Fish disease, diagnosis and treatment, $2^{\text {nd }}$ ed., Iowa St. Univ. Press, Iowa: 497pp.

Taher, M.M. (2014). Effects of stocking densities and feeding ratios on growth of common carp Cyprinus carpio cultivated in floating cages, Basrah-South Iraq. Ph.D. Thesis, Coll. Agric., Univ. Basrah: 112 pp. (In Arabic)

The fish site (2017). Available at: https://Thefishsite.com/diseaseguicle/whirling-disease. (Accessed on 18.12.2017)

Wikipedia (2017). Myxobolus cerebralis. Available at: https://en.wikipedia.org/myxoboluscerebra;is. (Accessed on 18.12.2017). 